\title{
The Epidemiology of Malaria in Prábis, Guinea-Bissau
}

\author{
Aldina Gonçalves, Paulo Ferrinho, Francisco Dias*
}

\begin{abstract}
Departamento de Saúde Pública, Instituto de Higiene e Medicina Tropical, Universidade Nova de Lisboa, Rua da Junqueira 96, 1300 Lisboa, Portugal *Laboratório Nacional de Saúde Pública, Ministério da Saúde Pública,

Guiné-Bissau
\end{abstract}

This article reports upon a community survey of malaria in Prábis, Guinea-Bissau. A house to house census of the population was initially carried out from August to December 1991(rainy season). After completing the census of each village, the population was invited to come, a week later, to a central point, where they were medically examined and finger-prick blood samples were collected for epidemiological characterization of the malaria situation in the area. The blood films of the one single village were used to compare the sensitivity and specificity of Polymerase Chain Reaction (PCR) with optical microscopy detection of parasites. In another village, the occurrence of parasitaemia was compared in children with and without fever.

During the dry season, from March to June 1992, the population in each village was again invited to come to a central point. Some of the field procedures were repeated.

The study revealed Prábis as an administrative Sector of Guinea-Bissau with endemic malaria, mostly due to Plasmodium falciparum, but with a significant rate of mixed infections. Active transmission occurred throughout the year, but it was more intensive during the rainy season and in the northwestern quadrant of the Sector. The level of endemicity of the villages varied from hypo to holoendemic. The factors associated with the differences among villages included village size and predominant economic activity (closeness to rice fields). The transmission paradigm was, most likely, a mixture of malaria of the African wet Savannah and malaria associated with irrigated paddy fields.

PCR proved to be a sensitive method with low specificity during the dry season. Pyraexia of $37.4^{\circ} \mathrm{C}$ or higher in children aged 2-9 years is not a sensitive indicator of parasitaemia but, it is highly specific and it has a clinically useful predictive value.

Key words: malaria - epidemiology - Africa - Guinea-Bissau

Malaria is still one of the major health problems in the developing world (Touzé 1990, Doberstyn 1991, Kondrachine 1992). GuineaBissau, in West Africa (Fig. 1), is no exception, with an estimated prevalence of $21 \%$ and a case fatality rate $0.2 \%$ (Nauclér et al. 1987).

The administrative Sector of Prábis is a rural and rice-growing area west of the capital city, Bissau. The population of 11,493 [53,9 inhabitants per $\mathrm{km}^{1}$, estimated with basis on the 1979 population census (Anonymous 1982)] is split in 17 ethnic groups, 3 religions (60\% Animists, 35\% Muslims and 5\% Christians) and 50 villages (Gonçalves 1995).

The villages consist of dispersed compounds: the larger ones are located along a central main road; other smaller villages are situated close to the rice fields. The typical house is made of mud with a grass roof. There is one government run health post in Prábis and one mission hospital for

This work was carried out with support of the "Junta Nacional de Investigação Científica e Tecnológica" (JNICT), Lisboa Portugal.

Received 13 December 1994

Accepted 6 October 1995 leprosy in Cumura. The hospital also runs a nearby health centre (the Cumura Health Centre) with polyclinic functions and with wards for the admission of sick children and pregnant women (Djatá 1991) (Fig. 1).

There is a dry season (December to April) followed by a rainy season. Malaria transmission is lower during the dry season and peaks in the rainy season, when the parasitaemic rate is greater in the villages situated on lowland, close to the paddy fields, than in the villages situated on the main road (Smedman et al. 1988). In 1985-1987 the villages were grouped into either meso or hyperendemic groups (Nauclér et al. 1987). The major malaria vectors in the Sector belong to the Anopheles gambiae complex (Correia 1973, Petrarca et al. 1982).

The first cases of chloroquine resistant malaria were documented in March 1990 (Hellgren et al. 1991), but the prevalence of resistance has not been estimated.

The objectives of the survey here described, the first carried out in the Sector, were to contribute to the knowlege of the epidemiology and clinical presentation of malaria, in order to advance with recommendations for adequate interventions. 


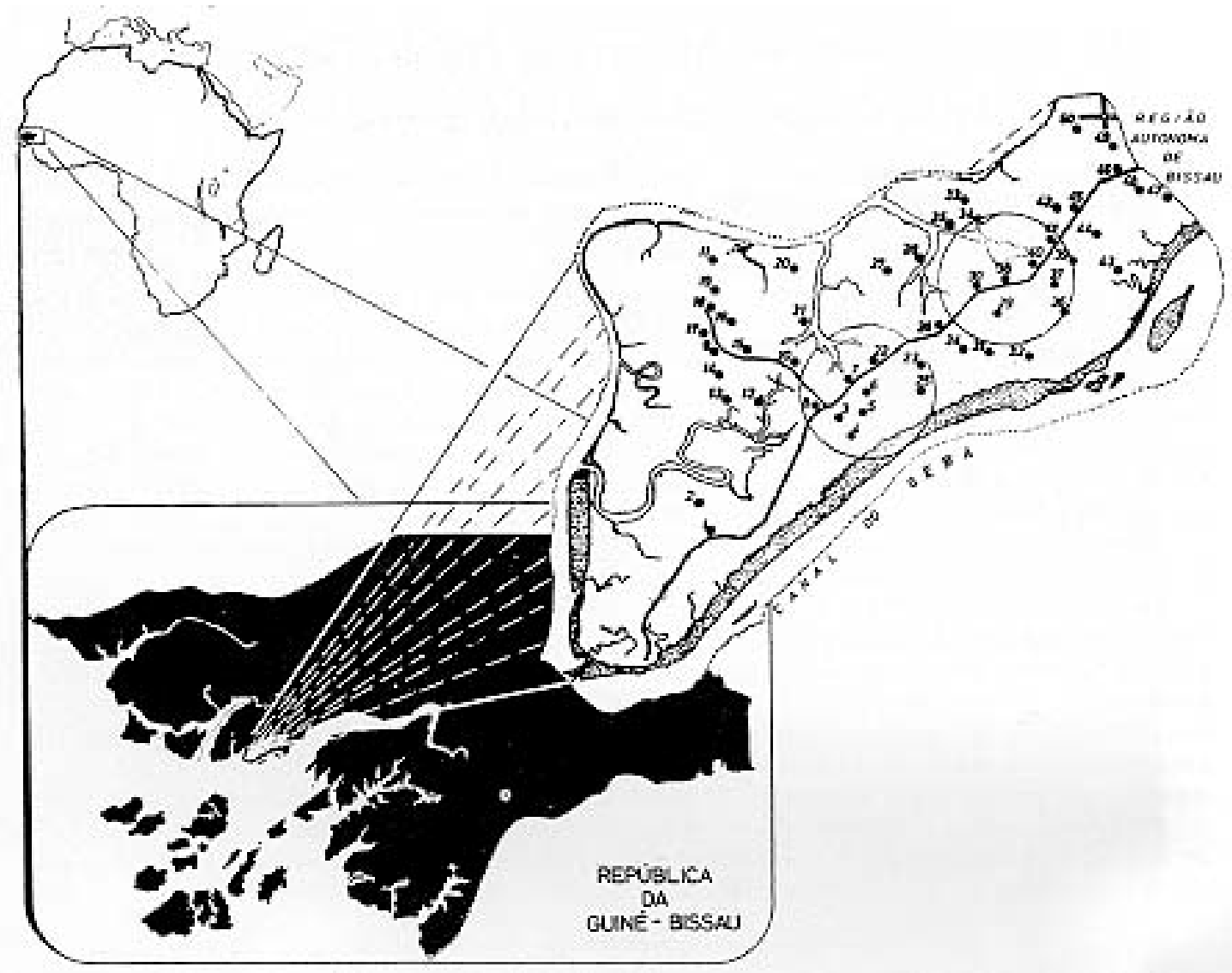

Fig. 1: sector of Prábis: number of villages and health facilities. The numbers corresponds to the localization of the villages and circles include areas within $5 \mathrm{~km}$ of functioning Health Services.

This survey, at the request of the ministry of Public Health, was also to serve as a pilot of a methodology to be applied in other sectors of the country.

\section{POPULATION AND METHODS}

A house to house census of the population was initially carried out from August to December 1991 (rainy season). After completing the census of each village, the population was invited to come, a week later, to a central point, in order to be medically examined and to collect blood samples for malaria. At the request of the Ministry of Public Health, people with malaria parasitaemia where given chloroquine, those with other pathologies were referred to the Cumura Health Centre.

The overall response rate was $75.4 \%(n=8668)$. For everyone, age and sex were recorded. A physician (G.A.) examined all children 2 to 9 years of age $(n=2974$ during dry season and 3042 during rainy season) for splenomegaly, in left lateral decubitus. Spleen size was graded according to Hacket's method (Anonymous 1964).

Blood samples by finger pricking were collected for thin and thick smears. The blood films were stained with Giemsa. At the local hospital Plasmodium forms were counted under oil immersion against 200 leukocytes. All the positive and $10 \%$ of the negative slides per village were reviewed by the staff of the National Laboratory of Public Health. If, on review, a negative slide showed positive, all the negative slides for that village were reexamined (Anonymous 1964, Payne 1988).

The blood films of one single village were used to compare the sensivity and specificity (as defined by Mausner \& Kramer 1985) of nested Polymerase Chain Reaction (PCR) with optical microscopy detection of parasites (for laboratory technical details see Snounou et al. 1993).

At Cumura village, the axilary temperature of children aged 2-9 years was, for 2 min, measured with a mercury thermometer.

During the dry season, from March to June 1992 , the population in each village was again invited to come to a central point. The same field procedures were repeated. The response rate was $56.3 \%(\mathrm{n}=6467)$.

All data were entered into EPIINFO 5 (Dean et al. 1990) and analyzed. 


\section{RESULTS}

The age distribution was similar for the two study periods and for strata of endemicity $(4 \%<1$ year old, $3 \% 1-<2$ years, $34 \% 2-9$ years, $13 \% 10$ 14 years and $45 \% 15$ years or older).

The ethnic composition of the villages varied between exclusively Balanta, Papel, Manjaco or mixed, with variations in population and household size (Table I).

The median number of people per household per village was $5.4 ; 22 \%$ of the Balanta, $41 \%$ of the Papel and $84 \%$ of the ethnically mixed villages had mean household size below this median.

The parasite was present in the human reservoir throughout the year. The Sector-wide prevalence of parasitaemia was similar for rainy (28\%) and dry (27\%) seasons, but the intensity of infec- tions, measured by the average parasite density per 200 leukocytes, was higher in the rainy season (47) than in the dry season (39) (t student test $\mathrm{p}<0,05)$.

The level of endemicity, as measured by the spleen rate in the 2-9 years age group, was higher during the dry season than the rainy season (Table II). The level of endemicity, as measured by the parasitaemia rate in the 2-9 years group was higher in the rainy than during the dry season. This second rate gave a more serious perspective of the level of endemicity of malaria in Prábis than the spleen rate (Table II).

Table III summarizes the sensivity, specificity and predictive value of PCR compared with optical microscopy. PCR is highly sensitive, but of low specificity and predictive value during the dry season.

TABLE I

Ethnic and population structure of the villages

\begin{tabular}{|c|c|c|c|c|c|c|}
\hline $\begin{array}{l}\text { Ethnic } \\
\text { group }\end{array}$ & $\begin{array}{l}\text { No. of } \\
\text { villages }\end{array}$ & $\begin{array}{c}\text { Total } \\
\text { population }\end{array}$ & $\begin{array}{c}\text { Total no. } \\
\text { households }\end{array}$ & $\begin{array}{c}\text { Average } \\
\text { population } \\
\text { per village }\end{array}$ & $\begin{array}{c}\text { Average } \\
\text { population } \\
\text { per househoud }\end{array}$ & $\begin{array}{c}\text { Average } \\
\text { househoud } \\
\text { per village }\end{array}$ \\
\hline \multirow[t]{2}{*}{ Mixed } & $18(36 \%)$ & $4718(49 \%)$ & $753(44 \%)$ & $337(45 \%)$ & 6.8 & 50 \\
\hline & & no data for 4 & no data for 3 & & & \\
\hline \multirow[t]{2}{*}{ Papel } & $21(42 \%)$ & $2665(28 \%)$ & $464(27 \%)$ & $140(19 \%)$ & 5.7 & 24 \\
\hline & & no data for 2 & no data for 2 & & & \\
\hline Balanta & $10(20 \%)$ & $2137(22 \%)$ & $469(28 \%)$ & $214(29 \%)$ & 4.6 & 47 \\
\hline Manjaco & $1(2 \%)$ & $57(<1 \%)$ & $7(<1 \%)$ & $57(8 \%)$ & 8.1 & 7 \\
\hline Total & $50(100 \%)$ & $9577(100 \%)$ & $1693(100 \%)$ & $748(100 \%)$ & - & - \\
\hline
\end{tabular}

TABLE II

Level of village endemicity according the splenic or parasitaemic rate (age group 2-9 years)

\begin{tabular}{|c|c|c|c|c|c|c|c|c|}
\hline \multirow{3}{*}{ Endemicity } & \multicolumn{4}{|c|}{ Parasitaemia } & \multicolumn{4}{|c|}{ Splenic rate } \\
\hline & \multicolumn{2}{|c|}{ Rainy season } & \multicolumn{2}{|c|}{ Dry season } & \multicolumn{2}{|c|}{ Rainy season } & \multicolumn{2}{|c|}{ Dry season } \\
\hline & No. of villages & Population & No. of villages & Population & No. of villages & s Population & No. of villages & S Population \\
\hline $\begin{array}{l}\text { Hypoendemic } \\
\text { (prevalence } 0-10 \% \text { ) }\end{array}$ & $1(2 \%)$ & $414(3 \%)$ & $0(0 \%)$ & $0(0 \%)$ & $4(8 \%)$ & $472(4 \%)$ & $1(2 \%)$ & $29(0.2 \%)$ \\
\hline $\begin{array}{l}\text { Mesoendemic } \\
\text { (prevalence 11-50\% }\end{array}$ & $24(49 \%)$ & $5802(48 \%)$ & $35(71 \%)$ & $9539(79 \%)$ & $45(92 \%)$ & $11590(96 \%)$ & $44(90 \%) 1$ & $1124(92 \%)$ \\
\hline $\begin{array}{l}\text { Hyperendemic } \\
\text { (prevalence } 51-75 \%\end{array}$ & $17(35 \%)$ & $4474(37 \%)$ & $13(27 \%)$ & $2477(21 \%)$ & $0(0 \%)$ & $0(0 \%)$ & $4(8 \%)$ & $909(8 \%)$ \\
\hline $\begin{array}{l}\text { Hyperendemic } \\
\text { (prevalence }>75 \%)\end{array}$ & $7(14 \%)$ & $1372(11 \%)$ & $1(2 \%)$ & $46(0.4 \%)$ & $0(0 \%)$ & $0(0 \%)$ & $0(0 \%)$ & $0(0 \%)$ \\
\hline
\end{tabular}

TABLE III

Sensitivity and specificity of PCR in comparison with Optic Microscopy

\begin{tabular}{|c|c|c|c|c|}
\hline & \multicolumn{2}{|c|}{ Dry season } & \multicolumn{2}{|c|}{ Rainy season } \\
\hline & \multicolumn{2}{|c|}{ Microscopy } & \multicolumn{2}{|c|}{ Microscopy } \\
\hline & Positive & Negative & Positive & Negative \\
\hline PCR positive & 11 & 25 & 19 & 2 \\
\hline PCR negative & 0 & 6 & 0 & 6 \\
\hline
\end{tabular}

Sensitivity $=100 \%$; Specificity $=19 \%$;

Predictive value of positive PCR $=31 \%$
Sensivity $=100 \%$; Specificity $=75 \%$; Predictive value of positive $\mathrm{PCR}=91 \%$ 
Relevant clinical and parasitological indices are summarized in Table IV. The main species of Plasmodium was P.falciparum in $98 \%$ of the cases. P.malariae was the second most common species, usually in mixed infections with P.falciparum. P.ovale was identified in two cases during the dry season and in three during the rainy season.

The degree of endemicity for each village according to season is reflected in Fig. 2. Most hyperendemic villages were clustered in the northwestern quadrant of Prábis. This quadrant consisted on 10 villages, surrounded by rice fields, with $10 \%$ of the Sector population. During the dry season the mean parasite density per village increased with the village population (Fig. 3). This was not observed for the rainy season $(\mathrm{r}=-0.05$, 95\% CI $-0.33<\mathrm{r}<0.22$ ).

Overall, there were 17 villages surrounded by rice fields. These were more likely to be hyper or holoendemic than the rest of the villages (OR $=2.15$, not significant, during the rainy season; and $\mathrm{OR}=16.20,95 \% \mathrm{CI} 1.96<\mathrm{OR}<171.1, \mathrm{p}=0.003$, during the dry season).

The sensitivity, specificity and predictive value of different levels of pyraexia are summarised in Table V. All levels of pyraexia are consistently of low sensitivity; specificity is always high; the predictive value seems clinically useful with pyraexias of $37.4^{\circ} \mathrm{C}$ or higher. The population attributable fraction for fever was:

0.39 in general - proportions of fevers in the reference age group that are attibutable to malaria parasitaemia. It equals the prevalence of fever in the population minus the prevalence of fever among those without parasitaemia, then divided by the prevalence of fever in the population; or

0,68 for those with parasitaemia - fraction of fever attributable to parasitaemia among people

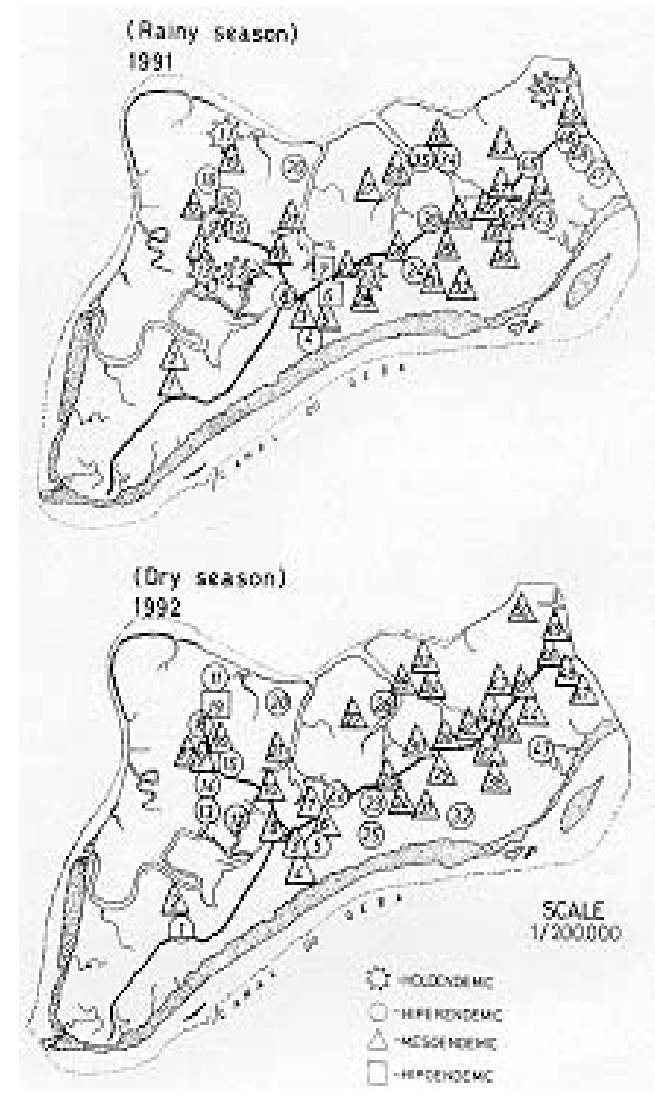

Fig. 2: level of endemicity during the dry and rainy seasons. The numbers correspond to those in Fig. 1 .

with parasitaemia. This equals the prevalence of fever among those with parasitaemia minus the prevalence of fever among those without parasitaemia, then divided by the prevalence of fever among those with parasitaemia.

\section{TABLE IV}

Parasitological and clinical indices according to the splenic or parasitaemic rate per village (age group 2-9 years)

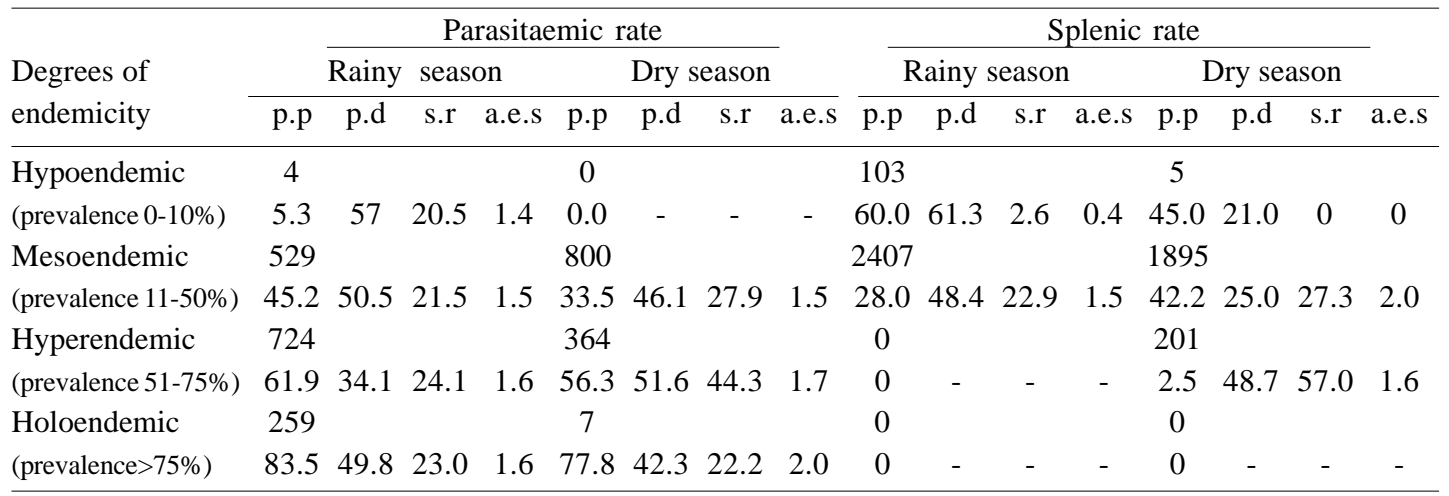

p.p: positive parasitology (\%); p.d: parasitic density; s.r: spleen rate (\%); a.e.s: average enlargement spleen 


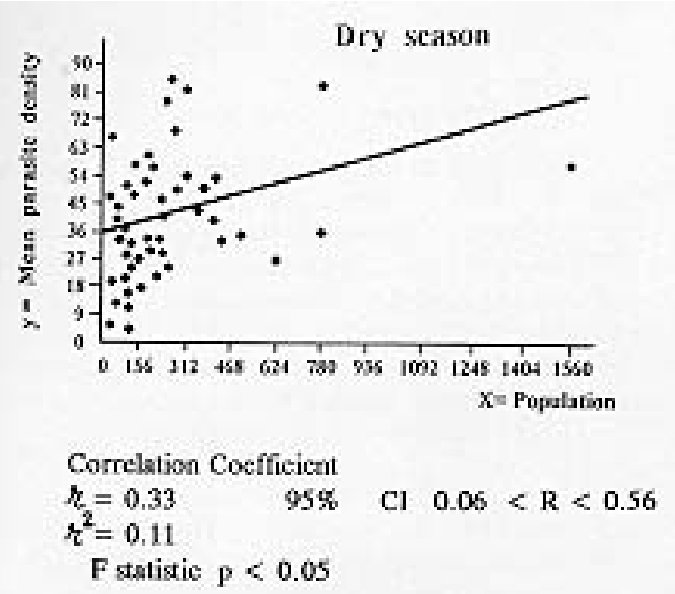

Regression cquation $y=60.65+4.28 x$

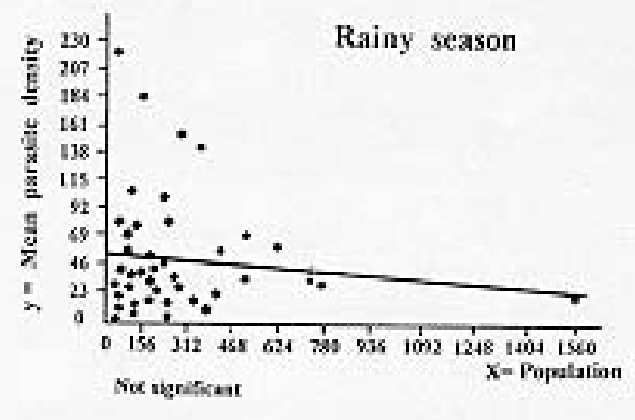

Fig. 3: scatter diagrams of mean parasite density per village population (age group 2-9 years).

\section{DISCUSSION}

The epidemiology of malaria - This study was the first sector-wide study of malaria prevalence in Prábis, and is part of a global study to be implemented in other regions of the country.

It confirmed that $P$. falciparum was the predominant species causing malaria in the Sector and that mixed infections accounted for about 3\% of all parasitaemias. This percentage was a gross underestimated of the true prevalence of mixed infections. As shown in previous studies, PCR identification of the Plasmodium species showed a prevalence of $26 \%$ to $36 \%$ of mixed infections, $75 \%$ of which involved P. falciparum and $P$. malariae (Snounou et al. 1993). As reported from elsewhere (Richard et al. 1988) infections restricted to $P$. malariae were very rare and this parameter was always associated with $P$. falciparum.

The study also gave a more serious picture of the degree of endemicity than previously suspected.

During the rainy season, the size of human settlement seemed of little relevance. But, during the dry season, as population size decreased so did the mean level of parasite density for the village. Closeness to rice fields was also an important determinant of level of endemicity. The northwestern quadrant of Prábis, far from all health services and isolated from the main road during the rainy season, seemed to have intense malaria transmission throughout the year. Ethnic composition and mean household size of the villages were not significant determinants of the epidemiological profile.

This study also raises questions as to the appropriate field techniques to assess the level of endemicity. The results obtained by the parasitaemic rate and by the spleen rate gave a very different picture of the level of endemicity of the infection. PCR, although very sensitive, is of low specificity and predictive value during the dry season. For the rainy season the sensitivity and predictive values are similar to those reported by Barker (Barker et al. 1989a).

Using different methods, the literature defines different levels of pyraexia to be used in morbidity surveys: $37.5^{\circ} \mathrm{C}$ (Greenwood et al. 1987) and $37.8^{\circ} \mathrm{C}$ (Cobban 1960). Our field work suggests $37.4^{\circ} \mathrm{C}$ as a clinically useful cut-off point. In Prábis malaria seems responsible for $39 \%$ of the pyraexias in children aged 2-9 years, similar to rates described from The Gambia (Greenwood et al. 1987).

In summary, Prábis is a Sector of GuineaBissau with endemic malaria, mostly due to $P$. falciparum, but with a significant rate of mixed infections. Active transmission occurred throughout the year, but it was most intense during the rainy season and in the northwestern quadrant of

TABLE V

Sensivity and specificity for parasitaemia of different levels of pyraexia in children aged 2-9 years

\begin{tabular}{cccc}
\hline Temperature & Sensivity & Specificity & Predictive value of the pyraexia \\
\hline$\geq 37.1$ & $9.4 \%$ & $95.4 \%$ & $47.6 \%$ \\
$\geq 37.2$ & $8.7 \%$ & $95.4 \%$ & $45.0 \%$ \\
$\geq 37.3$ & $7.7 \%$ & $96.7 \%$ & $50.0 \%$ \\
$\geq 37.4$ & $7.7 \%$ & $97.5 \%$ & $57.1 \%$ \\
$\geq 37.8$ & $7.7 \%$ & $97.9 \%$ & $61.5 \%$ \\
\hline
\end{tabular}


the Sector. The level of endemicity of the villages varied from the hypo to holoendemic. The factors associated with the differences among villages included village size and predominant economic activity (closeness to rice fields). The transmission paradigm was, most likely, a mixture of malaria of the African wet Savannah and malaria associated with irrigated paddy fields. The prevalence of chloroquine resistance is not known.

The implications for community health and clinical interventions - This study defined more clearly the epidemiology of the disease in Prábis. The seriousness of the picture of malaria does not mean past failure of control, seeing that effective control in Prábis, like in many other countries, has never been possible (Morrow et al. 1992). Prábis does not have the "necessary minimum" to meet the basic objectives of preventing death and reducing morbidity (Trigg 1991). This minimum should include appropriate levels of health personnel supported by well publicized policies and management protocols, accessible and appropriate diagnostic and treatment facilities, a sustainable supply of essential drugs and a well functioning referral system. These are not available in Prábis, where only $30 \%$ of the villages, with $40 \%$ of the Sector population, are residents within a radius of $5 \mathrm{~km}$ of the functioning health services (Fig. 1).

Malaria in Prábis is associated with the "total environment", i.e. the domestic as well as the as the agricultural environment in the rice fields. It is a disease recognized by the health workers and the community. It is therefore an ideal disease around which to mobilize the communities of the Sector. This will only be possible within a well structured system of primary health care (PHC) to support passive case finding and treatment of clinically apparent (fever of $37.4^{\circ} \mathrm{C}$ or higher, with no other clinically obvious symptomatology) cases and an active community based health education programme, in order to strengthen prevention of the disease in the community, with particular attention to the small villages in the northwestern quadrant and to small children and pregnant women (Anonymous 1979, Van der Kay 1991).

The cultural diversity of the population of the villages and the low population density, mean that the system of the PHC should be decentralized, should make effective use of front-line low-skills health workers, properly supported by the mobile teams, coordinated by one health centre with ready access to an effective referral system. Diagnostic, management and referral protocols should be clearly spelt out. Health education should be culture and economic activity sensitive. Operational objectives should be clearly defined within the context of a functioning Sector health information system.

\section{ACKNOWLEDGMENTS}

To Dr Virgilio do Rosário and Dr Lucilia Pinheiro (Centro de Malária e outras Doenças Tropicais) and Manuel A Coutinho (Departamento de Saúde Pública) IHMT Lisboa, Portugal; to Dr Georges Snounou, National Institute for Medical Research (Division of Parasitology) London, United Kingdom; to José LF Castro, LNSP, Bissau, Guinea-Bissau. To Frei Alberto Bocheto, Hospital de Cumura, Cumura Guinea-Bissau; and to Justino Évora, CMT, Bissau, Guinea-Bissau.

\section{REFERENCES}

Anonymous 1964. Terminologie du Paludisme et de l'Éradication du Paludisme. Organization Mondiale de la Santé, Genéve, 176pp.

Anonymous 1979. Expert Committee on Malaria, 17th Report. Tech Rep Ser 640. World Health Organization, Geneva, 80pp.

Anonymous 1982. Recenseamento Geral da População e da Habitação. Bissau: Departamento Central do Recenseamento, p. 344-356.

Barker Jr RH, Suebsaeng L, Rooney W, Wirth DF 1989. Detection of Plasmodium falciparum infection in human patients: a comparison of the DNA probe method to microscopic diagnosis. Am J Trop Med Hyg 41: 266-272.

Barker Jr RH, Brandling-Bennet AD, Koech DK, Mugambi M, Khan B, David R, David JR, Wirth DF 1986. Plasmodium falciparum: DNA probe diagnosis of malaria in Kenya. Exper Parasitol 69: 226-233.

Cobban KM 1960. Malaria in the partially immune adult Nigerian. J Trop Med Hyg 63: 233-237.

Correia MG 1973. O controlo do paludismo na ilha de Bissau - Guiné Portuguesa. Boletim Cultural da Guiné-Portuguesa XXVIII 110: 197-213.

Dean AD, Dean JA, Dicker RC 1990. Epi Info, Version 5: a Word Processing, Data Base and Statistics Program for Epidemiology on Microcomputers. Center for Disease Control, Atlanta, Georgia, USA, 373pp.

Djata P 1991. Relatório Anual. Direcção Regional de Biombo, Ministério da Saúde Pública. Bissau, Guinea-Bissau, 17pp.

Doberstyn EB 1991. Malaria research and control. Acta Leidensia 60: 9-11.

Gonçalves A 1995. Contribuição para o Controlo da Malária na Guiné-Bissau. Avaliação Epidemiológica no Sector de Prábis. $\mathrm{PhD}$ Thesis, Institute of Tropical Medicine and Hygiene, Universidade Nova de Lisboa, 258pp.

Greenwood BM, Bradley AK, Greenwood AM, Byass P, Jammeh K, Marsh K, Tulloch S, Oldfield FSJ, Hayes R 1987. Morbidity and mortality from malaria among children in a rural area of The Gambia, West Africa. Trans R Soc Trop Med Hyg 81: 478486.

Hellgren U, Johansson I, Dias F, Ericson O, Stenbeck J, Rombo L 1991. Chloroquine resistance $P$. falciparum malaria in Guinea-Bissau. Trans $R$ Soc 
Trop Med Hyg 85: 36.

Kondrachine AV 1992. Global malaria control strategy. An attainable goal, Abstract Vol. I, p. 12-13. In S Thravanij, W Fungladda, S Khusmith, O Pruekwatana (eds), Appropriate Technology for Better Health. XIII International Congress for Tropical Medicine and Malaria. Jommen, Pattaya, Thayland.

Mausner JS, Kramer S 1985. Epidemiology: an Introductory Text. p.217-220. 2nd ed. WB Saunders Company, Philadelphia.

Morrow RH, Bradley DJ, Najera JA, Thinnasarn K, Tanner M 1992. Failure in the control of malaria, a system analysis, Abstract Vol. I, p. 27. In S Thravanij, W Fungladda, S Khusmith, O Pruekwatana (eds), Appropriate Technology for Better Health. XIII International Congress for Tropical Medicine and Malaria. Jommen, Pattaya, Thayland.

Nauclér A, Dias F, Crato JF, Paquete EG, Martins P, Gomes MJ 1987. Estudo Epidemiológico do Paludismo na Guiné-Bissau, 1985-1987. Laboratório Nacional de Saúde Pública, Ministério da Saúde Públic, Bissau, Guinea-Bissau, 13pp.

Payne D 1988. Use and limitations of light microscopy for diagnosing malaria at the PHC level. Bull WHO 66: 621-626.
Petrarca V, Camara GC, Di Eco MA, Petrangeli G 1982. O Complexo Anopheles gambiae na Guiné-Bissau. Report of the Instituto di Parasitologia, Universitá de Roma "La Sapienza".13pp.

Richard A, Lallemant M, Trape JF, Carnevale P, Mouchet J 1988. Le paludisme dans la region forestiere de Mayombe, Republique Populaire du Congo. II. Observations parasitologiques. Ann Soc belge Méd trop 68: 305-316.

Smedman L, Gunnlaugsson G, Norrby E, Silva MC, Zetterstrom R 1988. Follow-up of the antibody response to measles vaccine in a rural area of GuineBissau. Acta Paediatr Scand 77: 885-889.

Snounou G, Pinheiro L, Gonçalves A, Fonseca L, Dias F, Brown K, do Rosario VE, 1993. The importance of sensitive detection of malaria parasites in the human and insect hosts in epidemiological studies, as shown by the analysis of field samples from Guiné-Bissau. Trans R Soc Trop Med Hyg 87: 649653.

Touzé JE 1990. Le paludisme en Afrique: incertitudes et perspectives. Médicine Tropicale 50: 9-10.

Trigg PI 1991. Drug use and design in the nineties. Acta Leidensia 60: 147-156.

Van der Kay HJ 1991. Malaria and control design in the nineties: What is to be expected. Acta Leidensia 60: 191-206. 
Epidemiology of Malaria in Guinea-Bissau - A Gonçalves et al. 